The price for a single number is $\$ 2.50$. Copies can be ordered from Joseph-E. Champagne, O.M.I., The Canadian Reseatch Center for Anthropology, Oblate Ave., Ottawa, Ontario, Canada.

\title{
Exhibition of African Art in Edinburgh
}

AN exhibition of African art in the Royal Scottish Museum, Edinburgh, from 24 February to 24 March, was organized under the auspices of the Munro Lectureship Foundation by the Department of Social Anthropology of Edinburgh University. Most of the exhibits were drawn from the collection of the Royal Scottish Museum, which gave its very generous cooperation in holding the exhibition; other loans were made by the British Museum, Glasgow Museum and Art Galleries, and private collectors.

The theme of the exhibition was the social and cultural context of African art. The following public lectures were given in conjunction with it: Mr. G. I. Jones on 'The Artist and the Community', Dr. R. E. Bradbury on 'The Art of Benin and Ife: (I) Artists and Patrons, (2) Art, Religion, and Society', Dr. M. J. Ruel on 'Convention in African Art'.

A catalogue was prepared for the exhibition by M. J. Ruel, some copies of which are still available.

\section{Linguistic Conference at the University of Dakar}

A Linguistic Conference, organized jointly by the University of Dakar and the West African Languages Survey and under the patronage of the President of the Senegal Republic, was held from 12 to 16 April. The programme was under the joint direction of Professors J. Berry and J. H. Greenberg; Professor R. G. Armstrong is the field director of the West African Languages Survey. Papers on a variety of linguistic topics were read in English and French and study groups were formed to discuss aspects of the Senegal-Guinea, Mande, Kwa, and Gur languages. There were eleven African participants among the total of forty-one from universities in Africa, Europe, and the United States.

\section{Establishment of the Institute of African Studies at the University of Ghana}

THE Institute of African Studies at the University of Ghana at Legon has at present a staff of five Research Fellows and a Director. There are three linguists, an historian, and a musicologist, but it is hoped to add to these in $1962-3$ an economist, a social anthropologist, a specialist in Arabic and Hausa, and an Islamic historian. A Music and Arts Division of the Institute has been created and will have initially four Research Fellows-two for music, one for dance and art, and one for literature. In addition the Institute hopes to invite a number of Visiting Professors and Lecturers from Britain, America, Russia, Mali, and other parts of Africa to give courses or open lectures in their own special fields. Associate membership of the Institute will be offered to members of teaching departments as well as to scholars abroad who might want to visit Ghana.

The present members of the Institute are carrying out research projects in Ghana in their own fields. Investigations into musicological problems have continued as well as ethnohistotical research into the formation of states, trade routes, and allied historical subjects. One of the three linguists is working on Dagbani and will shortly begin a survey of the languages of Northern Ghana. The second linguist is working on Akan, and the third on Guan, Togo Remnant languages, and Ewe. The last has been co-operating with the historian in the Institute and an archaeologist on investigations into Guan-Mande settlements. The Institute has been supporting research by members of teaching departments on the basis of individual applications; so far most of the requests for assistance have come from the Departments of History and Philosophy. As soon as funds are available the Institute hopes 